\title{
1 The stratigraphic record of changing hyperaridity in the Atacama Desert over the
}

2 last $\mathbf{1 0} \mathbf{~ M a}$

3 Alberto Sáez ${ }^{1^{*}}$; Lluís Cabrera ${ }^{1}$; Miguel Garcés ${ }^{1}$, Paul van den Bogaard ${ }^{2}$, Arturo Jensen ${ }^{3}$, Domingo

4 Gimeno $^{4}$

$5{ }^{1}$ Departament d'Estratigrafia, Paleontologia i Geociencies Marines, Grup de Geodinàmica i Anàlisi de Conques,

6 Universitat de Barcelona, Spain. *Corresponding author: a.saez@ub.edu

$7 \quad{ }^{2}$ GEOMAR | Helmholtz Centre for Ocean Research Kiel, Germany

$8 \quad{ }^{3}$ Departamento de Ciencias Geológicas. Universidad Católica del Norte. Antofagasta, Chile.

$9 \quad{ }^{4}$ Departament de Geoquímica, Petrologia i Prospecció Geológica. Universitat de Barcelona, Spain.

\section{ABSTRACT}

12 New radiometric and magnetostratigraphic data from Quillagua and Calama basins (Atacama Desert) 13 indicate that the stratigraphic record over the last $10 \mathrm{Ma}$ includes two hiatuses, lasting approximately 2 and 4 14 million years respectively. These sedimentary gaps are thought to represent prolonged periods of 15 hyperaridity in the region, with absence of sediment production and accumulation in the central depressions. 16 Their remarkable synchrony with Antarctic and Patagonian glacial stages, Humboldt cold current 17 enhancement and cold upwelling waters lead us to suggest long-term climate forcing. Higher frequency climate (orbital precession and eccentricity) forcing is thought to control the sequential arrangement of the

19 lacustrine units deposited at times of lower aridity. Hyperaridity trends appear to be modulated by the activity of the South American Summer Monsoon, which drives precipitation along the high altitude areas to the east of Atacama. This precipitation increase combined with the eastward enlargement of the regional drainage during the late Pleistocene enabled water transfer from these high altitude areas to the low lying closed Quillagua basin and resulted in the deposition of the last widespread saline lacustrine deposits in this depression, before its drainage was open to the Pacific Ocean.

Keywords: Late Neogene, Antarctic and Patagonian Glaciations, Humboldt Current, South American Summer Monsoon, hyperaridity.

\section{Introduction}

The Atacama Desert has existed for approximately 15 million years (Hartley and Chong, 2002; Le Roux, 2012). This subtropical hyperarid desert is of great geologic interest because its climatic evolution has been 
controlled by two major tectonic and paleoceanographic forces such as: (1) the uplift of the Central Andes with its Atlantic rain shadow effect; and (2) the intensity of the cold water advection fed by the Humboldt Current and its control on the temperature of the coastal upwelling water that modulates the strength of the subtropical anticyclone. The east-west sea surface temperature contrast over the SE Pacific would be finally the most significant factor leading to more or less hyperaridity (Garreaud et al., 2010 and references therein). In addition, the water balance in Atacama is found to be modulated at higher frequency time scales by the South American Summer Monsoon (SASM) that contributes with precipitation along the higher altitude areas that fringe the eastern margins of the region (Betancourt et al., 2000).

Climatic studies of the Late Cenozoic of the Atacama region have been focused on establishing the age and driving mechanism leading to hyperarid conditions (Gaupp et al., 1999; Hartley and Chong, 2002; Hartley, 2003; Dunai et al., 2005; Hoke et al. 2007; Houston et al., 2008, Evenstar et al., 2009, Rech et al., 2006, 2010 among others). Crucial for the reconstruction of past environments and the understanding of the evolution of this region is the achievement of a reliable absolute chronology of the stratigraphic record. New radiometric and magnetostratigraphic data from the Quillagua Basin infill are presented here, which identifies alternating periods of active sedimentation and of long-lasting non-depositional hiatuses. A chronostratigraphic correlation with adjacent basins in the Atacama and Altiplano regions, as well as a comparison with the chronology of paleoclimatic and paleoceanographic changes at higher southern latitudes was carried out in order to assess the contribution of climatic forcing to the sedimentary record of the Atacama region.

\section{Methods}

A total of fourteen tephra layers from 10 sections in the basin center and the eastern basin margin were dated by ${ }^{40} \mathrm{Ar} /{ }^{39} \mathrm{Ar}$ step-heating. Sample preparations were carried out at the Petrology Laboratory of the University of Barcelona. Biotite and feldspar crystals were hand-picked from crushed and sieved splits and cleaned using an ultrasonic disintegrator. Separates were placed in aluminum trays and irradiation cans wrapped in $0.7 \mathrm{~mm}$ cadmium foil and neutron irradiated at the 5-MW reactor of the Helmholtz-Zentrum 60 Geesthacht (HZG).

Age determinations were carried out by laser ${ }^{40} \mathrm{Ar}{ }^{39} \mathrm{Ar}$ step-heating at the Helmholtz Centre for Ocean Research Kiel (GEOMAR). After purification the gas samples were analyzed using a MAP 216 series noble gas mass spectrometer. Raw mass spectrometer peaks were corrected for mass discrimination, background and blank values (measured every fifth analysis). The neutron flux was monitored using Taylor Creek 
Rhyolite Sanidine (TCR-2: $27.87 \pm 0.04 \mathrm{Ma}$; Lanphere and Dalrymple, 2000). Corrections for interfering neutron reactions on $\mathrm{Ca}$ and $\mathrm{K}$ are based on analyses of optical grade $\mathrm{CaF}_{2}$ and high-purity $\mathrm{K}_{2} \mathrm{SO}_{4}$ salt crystals that were irradiated together with the samples. Alteration states were monitored according to Baksi (2007).

A total of 196 oriented paleomagnetic samples were drilled in situ at evenly distributed stratigraphic intervals of 2 meters approximately, avoiding the coarser grained intervals. All samples were routinely stepwise demagnetized using a shielded furnace and the remanent magnetization measured in a three-axis superconducting magnetometer hosted at the Paleomagnetic Laboratory of the University of Barcelona and CSIC. Complete demagnetization often required $>10$ demagnetization steps up to peak temperatures of $600^{\circ} \mathrm{C}$, while demagnetization curves revealed unblocking temperatures preferentially ranging between 500 and $600^{\circ} \mathrm{C}$. The high average NRM and the steep remanence decay at temperatures below $600^{\circ} \mathrm{C}$ was related to the abundance of magnetite of volcanic source, either as fallout contribution from active volcanoes or reworked from older eruptions.

Visual inspection of the demagnetization diagrams (Supplementary Fig. 1) allowed the identification of a northerly up viscous component which parallels the present day field and demagnetizes at temperatures below $300^{\circ} \mathrm{C}$. A Characteristic Remanent Magnetization (ChRM) is identified in the temperature interval ranging from $300^{\circ} \mathrm{C}$ to $600^{\circ} \mathrm{C}$, with a relatively high average intensity of $6.78 \mathrm{~mA} / \mathrm{m}$. The direction of the ChRM component was calculated by means of principal component analysis in 155 samples ( $80 \%$ of the total demagnetized samples). Virtual Geomagnetic Pole (VGP) latitudes were calculated for each paleomagnetic direction and a polarity interpretation was derived from each sample (Supplementary Figure 2). Normal and Reversed polarity magnetozones are indicated in the polarity logs as black and white intervals respectively. Single-site magnetozones are indicated as half-width polarity intervals in the polarity log (Supplementary Figure 2), but not considered sufficiently reliable, and not taken into account for correlation purposes.

A feasible correlation of the local magnetostratigraphy of Quillagua with the Geomagnetic Polarity Time Scale (Gradstein et al., 2004, Figure 2) is put forward on the basis of the several ${ }^{40} \mathrm{Ar} /{ }^{39} \mathrm{Ar}$ ages obtained from tephra layers interbedded within the sequence (Table 1).

\section{Quillagua and Calama basins records}

The Quillagua Basin ( $21^{\circ}-22^{\circ} 40^{\circ} \mathrm{S}, 800-2000$ masl.) is a north-south oriented basin located in the southern part of the Central Depression or Pampa del Tamarugal, between the Coastal Range and the 
Precordillera (Fig. 1), presently draining to the Pacific Ocean through the Loa River Canyon (Fig. 1). From late Miocene to Pleistocene, this basin was internally drained, leading to the accumulation of nearly 200 meters of alluvial sediments, interbedded with three lacustrine units and some tephra layers in the central part of the basin (Jensen, 1992; Sáez et al., 1999; Pueyo et al., 2001) (Fig. 2). Well developed fluvial fan

101 deposits in the eastern basin margin consist mainly of conglomerates that merge basinward into fine-grained sandstones and red mudstones, sourced from the Western Cordillera (i.e., Arcas Fan deposits, Kiefer et al., 1997). Minor fluvial sandstone and gravel contributions from the south corresponding to paleo-Loa River deposits also occur. From old to young, the lacustrine units consist of gypsum-anhydrite deposits (Hilaricos Unit), diatomite, marls, silty limestone, gravelly sandstone and minor tufa deposits (Quillagua Fm) and halite (Soledad Fm).

Deposits of Quillagua Fm are 130 m-thick and paraconformably overlie alluvial red beds in Qda. Temblor (site 3), whereas in Puente Posada (site 4) these deposits rest unconformably over similar alluvial facies (Figs. 1 and 2). Stratigraphy, sedimentology and paleogeography of this unit have been extensively analyzed previously elsewhere (Sáez et al., 1999; Bao et al., 1999; Pisera and Sáez, 2003) and its description is

111 beyond the scope of this contribution. In the inner-central basin zone, between Cerro Mogote and Qda.

112 Temblor sites, Quillagua Fm deposits are organized in two cycles of expansion and retraction of lacustrine 113 facies (4th-order cycles), each of them arranged in $\sim 20$ 5th-order transgressive-regressive lacustrine cycles 114 (Fig. 2) (Sáez et al., 1999; Bao et al., 1999). The halite sequence of the Soledad Fm is 100 m-thick, shows 115 physical continuity with saline deposits of the Salar Grande and unconformably overlies Hilaricos unit in the sector of Lomas de la Sal (Pueyo et al., 2001).

The Late-Pleistocene Soledad Formation was deposited from water contributions of the ancient Loa River 118 that currently collect water contribution from extense high altitude zones located to the East of the Atacama 119 Desert and yields an average permanent flow of $2.43 \mathrm{~m}^{3} / \mathrm{s}$. Nevertheless, the spill of the Loa River into the 120 Pacific Ocean resulted in a drop of $\sim 1000 \mathrm{~m}$ of the base level that triggered the present entrenchment phase 121 of the central areas in the basin, preventing further accumulation of extensive lacustrine deposits since water was not retained any longer in the basin.

123 Towards the eastern margin, the basin infill is up to a 600 hundred $\mathrm{m}$-thick and consists of a syntectonic 124 red bed sequence that encompasses alluvial deposits, dated from 24.0 to almost 5.8 Ma (Tomlinson et al., 125 2001; Hoke et al., 2007). So far, in the inner basin zone, only the lower and mid-intervals of the stratigraphic 126 sequence have been dated. K/Ar on biotites, yield an age of 6.0 and 5.8 Ma for the Hilaricos and Quillagua 127 deposits respectively (Sáez et al., 1999). 
The Calama Basin $\left(22^{\circ}-23^{\circ} \mathrm{S}, 2000-3000\right.$ masl.) is a depression situated between the Precordillera and the Western Cordillera (Fig. 1) and it is currently drained to the Pacific Ocean by the Loa River catchment

130 (Fig. 1). The drainage communication between the Calama and Quillagua basins ranged from closed131 restricted to open during their evolution, due to the likely development of tectonic thresholds (Sáez et al., 132 1999; May et al., 1999). Early Miocene to Recent alluvial systems spread from different source areas located 133 around the basin margins. Basin sedimentation was not continuous but during some time intervals nearly 134250 meters of alluvial and lacustrine sediments were accumulated at the central and southern sectors or the 135 basin (Chiquinaputo, Opache, Chiu-Chiu Fms). Some tephra layers have been reported in these sequences 136 (May et al. 1999, 2005; Blanco, 2008).

137 The Chiquinaputo Fm includes minor diatomite and carbonate tufa interbedding red alluvial deposits. In 138 the southern basin sector this unit unconformably overlies Lasana or Jalquincha Fms deposits and it 139 includes at its bottom an ignimbrite dated to 10.3/9.4Ma (Blanco, 2008) and another volcanic layer at the top 140 dated to $7.82 \mathrm{Ma}$ (Rech et al., 2010). The Opache Fm is composed by carbonate-cemented conglomerate 141 and sandstone, limestone and diatomaceous marl that have been dated between 5.76 and 3.37 Ma thanks 142 to two volcanic ash layers interbeded near the bottom and the top of the formation (May et al., 2005). The 143 Chiu-Chiu Fm unconformably overlies folded strata of Opache Fm, includes diatomite and carbonate tufa 144 interbedding clastic deposits. This unit has been imprecisely dated between 3.37 Ma of the top of Opache $145 \mathrm{Fm}$ and $0.45 \mathrm{Ma}$ of the overlying swampy fluvial deposits (Blanco 2008). Despite the reported differences in 146 the dating of the diverse sedimentary units, several authors have reported long sedimentary gaps between 147 Jalquincha/Lasana and Opache Fms and between Opache and Chiu-Chiu Fms (May et al, 2005; Blanco, 148 2008; Rech et al 2010).

\section{Results}

Results of the ${ }^{40} \mathrm{Ar} /{ }^{39} \mathrm{Ar}$ laser step-heating analyses are listed in Table 1. The tephra layers studied from 153 the basin center and the eastern alluvial basin margins yield ages that cluster into three distinct groups: from 1547.8 to $8.8 \mathrm{Ma}$ (Hilaricos Fm), from 5. 0 to $5.6 \mathrm{Ma}$ (Quillagua Fm), and Late Pleistocene (0.1 to $0.2 \mathrm{Ma}$; 155 Soledad Fm).

156 The magnetostratigraphic study carried in the Quillagua Basin which complements the isotope 157 geochronology, providing a detailed chronostratigraphic framework for the basin infill. Three partially overlapping sections in the basin center were sampled for this purpose, and 155 samples were stepwise 
yielded a consistent pattern of reversals, with a number of samples/magnetozone sufficient to ensure completeness of the magnetostratigraphic record. The derived magnetostratigraphy consists, however, of a remarkably low number of reversals compared to the age range presumed from radiometric dating. Given these radioisotopic constraints, the low number of reversals recorded in the sequence indicates that very significant sedimentary gaps must exist, so that periods of sedimentation in the basin represent less than half of the total time span. On the basis of the available radiometric constraints, a correlation with the geomagnetic polarity time scale is proposed (Fig. 2), where two sedimentary hiatuses on the order of millions years each are inferred.

The comparison of the Late Cenozoic stratigraphic records of Quillagua and Calama basins shows significant parallelism, in terms of chronology of depositional units, hiatuses, as well as sedimentation rates. Thus, a very low, long-term sedimentation rate $(\sim 2.0 \mathrm{~cm} / \mathrm{kyr})$ is recorded in the inner Quillagua Basin. Net sediment accumulation only occurred during three relatively short periods lasting a total of $2.9 \mathrm{Ma}$ to record the 185 m-thick sequence. Non-depositional intervals spanned $70 \%$ of the last $10 \mathrm{Ma}$. From published stratigraphic data from the central parts of the Calama Basin (Tomlinson et al., 2001; Blanco, 2008; Blanco and Tomlinson, 2009) the sedimentation rate can be calculate in $\sim 2.3 \mathrm{~cm} / \mathrm{kyr}$. Both basins show a relative synchronicity in the evolution of lacustrine and alluvial environments as well (Fig. 3), suggesting that a major leading regional factor controlled the overall depositional history.

\section{Discussion: Climate forcing}

Tectonic and geomorphologic factors have been regarded as determinant controls for the sedimentation in the Central Depression (Naranjo and Paskoff, 1982; Houston et al., 2008). However, the recurrent expansion of neogene lacustrine units in the internally drained Quillagua Basin can be well regarded as climatically controlled. The fairly good fit between major non-sedimentary and sedimentary periods between Quillagua and Calama basins and between other records in the region (i.e. upper Salar Grande and Salar de Atacama basins), lead us to propose that the major forcing factor in the Atacama region was the oscillation from hyperarid to less arid climatic conditions. The hyperarid climate conditions correlate with hiatuses in the central basin areas as a result of lack of sediment production; and the less arid conditions to low alluvial and lacustrine sedimentation rates.

Our chronology is a step towards recognizing the importance of climate forcing in the fluvial-lacustrine records of the Quillagua Basin (Saéz et al., 1999). Small meter-scale transgressive-regressive lacustrine sequences have an average duration of $20 \mathrm{kyr}$, thus most likely representing precession cycles. These are organized into lower order sequences with a mean duration close to the 400-kyr eccentricity period (Fig. 3). 
At a larger scale, the sediments of the inner or distal zones of the Quillagua and Calama basins are organized into units separated by long-lasting sedimentary gaps, these features interpreted as the response

to the long-term oscillations of climate, shifting from arid to hyperarid conditions. The presence of unconformity surfaces and abrupt changes of lithology, both matching with the sedimentary hiatuses, strengthen the interpretation of the existence of these long periods of no sedimentation in the Quillagua Basin (Fig. 2).

The new integrated chronostratigraphy of the Quillagua and Calama basins allows a correlation with records of global and regional climate change found to have an effect on the continental paleoenvironments of South America. The growth of the Western Antarctic ice-sheet (Zachos et al., 2001), coeval to times of full glaciation in Patagonia (Rabassa et al., 2005), as well as cold seawater paleotemperatures on the Peru coast (Abe et al., 2006; Tiedemann and Mix, 2007; Amiot et al., 2008) have been recorded between 7 and

$2045.5 \mathrm{Ma}$. Seawater cooling was related to the intensification of the Humboldt Current, with equatorward advection and upwelling of cold subpolar waters in connection with glaciation in Antarctica and the oceanic thermocline shallowing (Dekens et al., 2007). Cold water along the western border of subtropical South America strengthened the regional anticyclone and triggered hyperarid phase 1 that resulted in Gap 1 (Fig. 3). Conversely, during the subsequent early Pliocene warm period coeval with ice sheet retreat in Antarctica (Haywood et al., 2008) and in Patagonia (Rabassa et al., 2005) the Humboldt current weakened and the 210 temperature of upwelled coastal water along the Chile-Peru coastal region was warmer from c. 4.6-3.1 Ma 211 due to the oceanic thermocline deepening, as expected during permanent El Niño-like conditions (Dekens et 212 al., 2007). Warm seawater over the adjacent southeast Pacific Ocean weakened the subtropical anticyclone 213 and triggered higher precipitation (Garreaud et al., 2010) that resulted in the deposition of alluvial-lacustrine 214 sequences (Quillagua and Opache Fms) in the central basin zones (Fig. 2). Renewed water cooling linked to 215 the spreading of the Antarctic Ice sheets to their present polar cold stage between 3 and $2.5 \mathrm{Ma}$ (Naish et 216 al., 2008; Fig. 3) and the renewed cold water upwelling in the tropical-subtropical eastern Pacific embracing 217 the Pliocene/Pleistocene transition (Wara et al., 2005) triggered the currently ongoing second hyperarid 218 phase in Atacama that generated Gap 2.

219 The Soledad Fm, together with other coeval lacustrine deposits (Chiu-Chiu Fm in Calama Basin; upper 220 halite deposits at the Salar Grande and Salar de Atacama Basin; Pueyo et al., 2001; Bobst et al., 2001) 221 record basin evolution stages with higher water contribution that modulated the overall hyperarid Phase 2. 222 Both climatic and geomorphic factors are proposed to explain this water contribution that triggered the 223 sedimentation of Soledad Fm in the Quillagua basin before it was opened to the Pacific Ocean. From a 
climatic point of view, increase of precipitation in the higher altitude regions located to the East of the Atacama region seems to be linked to the prevailing La Niña-like conditions (Betancourt et al.,2000) and could afford for episodes of larger water income into the lower altitude zones. From a geomorphic point of view the eastward enlargement of the Loa river catchment would have triggered and enabled a larger water contribution from the higher altitude catchments located to the East of Atacama Desert.

The late Pleistocene lacustrine episodes in the Atacama region (Soledad Fm., Salar Grande, Chiu-Chiu, 230 Salar de Atacama) were coeval with a deep-lake, moist stage cycle (Ouki phase) that occurred between 120 231 and $98 \mathrm{ka}$ in the Andean Altiplano Poopo Basin (Placzek et al., 2006). Moreover, Nester et al. (2007) and 232 Latorre et al. (2006) have reported younger late Pleistocene water discharge episodes in the Central 233 Depression, these also coeval with spreading and deepening of lakes in the Altiplano. These water 234 contribution increases have been attributed to intensification of the SASM in its turn related to pronounced 235 equatorial sea surface temperature gradients under persistent La Niña-like conditions at different (i.e. 236 centennial to millennial) time scales (Betancourt et al., 2000). Rech et al. (2006) suggested that these 237 conditions may have occasionally increased water contribution into the Atacama region from its eastern 238 higher altitude margins even since Middle Miocene.

239 We conclude that million year-scale, sedimentary hiatuses developed in the Atacama region were coeval 240 to (1) growth of ice volume in Antarctica and Patagonian glaciers; and (2) cold water periods in the 241 neighboring ocean, as a consequence of the reinforcement of the Humboldt Current and cold water 242 upwelling. Climate forcing is thus proposed for the Late Neogene stratigraphic record in the Atacama region, 243 where cooling stages sustained extreme hyperarid conditions, these accounting for the occurrence of 244 prolonged sedimentary gaps in the central depressions (Fig. 3). The development of the extensive late 245 Pleistocene saline lacustrine deposits in the Quillagua basin under the ongoing hyperarid conditions resulted 246 from a combination of increasing precipitation in the higher altitude catchments to the East of Atacama 247 Desert and of water transfer to the low lying basins enhanced by the likely eastward enlargement of the Loa 248 river catchment.

\section{Acknowledgments}

This research was funded by Spanish Government projects: PB94-0901, CGL2004-00780, CGL200766431-C02-02/BTE, CGL2007-60932/BTE and CGL2010-17479; and by Generalitat de Catalunya through

254 Research Institute GEOMODELS and the Research Group of "Geodinàmica i Anàlisi de Conques" (2009 255 GGR 1198). Thanks are due to A. Carroll, C. Connors and E. Gierlowski by the critical reading of an early 
256 version of this paper. We are grateful to Teresa Jordan, Rene Garreaud, two anonymous reviewers and the 257 EPSL editor for their useful revisions and comments that enabled us to precise the paper content. 


\section{References}

Abe, C., Yamamoto, M., Irino,T., 2006. Data report: organic carbon and biomarker variations, Sites 1237 and 1239. In Tiedemann, R., Mix, A.C., Blum, P. and Ruddiman, W.F. (Eds). Proceedings of the Ocean Drilling

261 Program, Scientific Results, 202: College Station, TX (Ocean Drilling Program), 1-14.

Amiot, R., Göhlich, U.B., Lécuyer, C., de Muizon, C., Cappetta, H., Fourel, F., Héran, M-A., Martineau, F.,

2008. Oxygen isotope compositions of phosphate from Middle Miocene-Early Pliocene marine vertebrates of

Peru. Palaeogeography, Palaeoclimatology, Palaeoecology, 264, 85-92.

Baksi, A.K., 2007. A quantitative tool for detecting alteration in undisturbed rocks and minerals - I: Water, chemical weathering, and atmospheric argon, in: Foulger, G.R., Jurdy, D.M. (Eds), Plates, Plumes and

Bao, R., Sáez, A., Servant-Vildary, S., Cabrera, L., 1999. Lake-level and salinity reconstruction from diatom analyses in Quillagua Formation (Late Neogene, Central Andean Forearc, Northern Chile).

Palaeogeography, Palaeoclimatology, Palaeoecology 153, 309-335.

Blanco, N., 2008. Estratigrafía y evolución tectono-sedimentaria de la cuenca cenozoica de Calama (Chile, $22^{\circ}$ S). M.S. Thesis. University of Barcelona. 68 p. (Spanish).

Blanco, N., Tomlinson, A., 2009. Carta Chiu Chiu, Región de Antofagasta. Servicio Nacional de Geología y Minería, Carta Geológica de Chile, Series Basic Geology. 26 p., Scale 1:50.000. Santiago.

Betancourt, J.L., Latorre, C., Rech, J.A., Quade, J., Rylander, K.A., 2000. A 22,000-year record of monsoonal precipitation from Northern Chile's Atacama Desert. Science 289, 1542-1546.

Bobst, A.L., Lowernstein, T.K., Jordan, T. E., Godfrey, L.V., The-Lung Ku, and Shangde Luo, 2001. A 106

Ka paleoclimate record from drill core of the Salar de Atacama, northern Chile. Palaeogeography,

Palaeoclimatology, Palaeoecology 173, 21-42.

Dekens, P.S., Ravelo, A.C., McCarthy, M.D., 2007. Warm upwelling regions in the Pliocene warm period. Palaeceanography 22, PA3211. 
291 Dunai, T.J., Gonzalez, G.A., Juez-Larré, J., 2005. Oligocene-Miocene age of aridity in the Atacama Desert revealed by exposure dating of erosion sensitive landforms. Geology 33, 321-324.

Garreaud, R.D., Molina, A., and Farias, M., 2010. Andean uplift, ocean cooling and Atacama hyperaridity. A climate modeling perspective. Earth and Planetary Science Letters 292, 39-50.

Gaupp, R., Kött, A., Wörner, G., 1999. Paleoclimatic implications of Mio-Pliocene sedimentation in the highaltitude intra-arc Lauca Basin of northern Chile. Palaeogeography, Palaeoclimatology, Palaeoecology 151, 79-100.

Gradstein, F.M., Ogg, J.G., Smith A., 2004. A Geologic Time Scale 2004. Cambridge University Press,

Harley, A.J., 2003. Andean uplift and climate change. Journal of the Geological Society of London 160, 7-10.

Hartley, A.J., Chong, G., 2002. Late Pliocene age for the Atacama Desert. Implications for the desertification of western South America. Geology 30, 43-46.

Haywood, A.M., Smellie, J. L., Ashworth, A. C., Cantrill, D.J., Florindo, F., Hambrey M. J., Hill, D., Hillenbrand, C., Hunter, S.J., Larter, R.D., Lear, C.H., Passchier, S., van de Wal, R., 2008. Middle Miocene

311 to Pliocene History of Antarctica and the Southern Ocean. Developments in Earth \& Environmental Sciences $3128,401-463$.

314 Kiefer, E., Dörr, M.J., Ibbeken, H., Götze, H-J., 1997. Gravity-based mass balance of an alluvial fan giant:

315 the Arcas Fan, Pampa del Tamarugal, Northern Chile. Revista Geológica de Chile 24, 165-185.

317 Hoke, G. D., Isacks, B.L., Jordan, T.E., Blanco, N., Tomlinson, A.J., Ramezani, J., 2007. Geomorphic 318 evidence for post-10 Ma uplift of the western flank of the central Andes 18³0'-22ºS. Tectonics 26, TS5021. 
Houston, J., Hart, D., Houston, A., 2008. Neogene sedimentary deformation in the Chilean forearc and implications for Andean basin development, seismicity and uplift. Journal of Geological Society, London 165, 291-306.

Jensen, A., 1992. Las cuencas aluvio-lacustres oligoceno-neógenas de la region de ante-arco de Chile

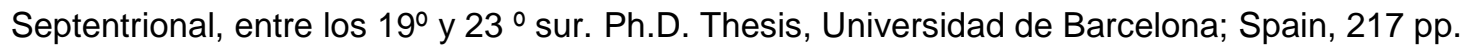

Lanphere, M.A., Dalrymple, G.B., 2000. First-principles calibration of 38Ar tracers: Implications for the ages of 40Ar/39Ar fluence monitors. U.S. Geological Survey Professional Paper 1621, 10 p.

Latorre, C., Betancourt, J.L., Arroyo, M.T.K. , 2006. Late Quaternary vegetation and climate history of a perennial river canyon in the Rio Salado basin (22 degrees S) of Northern Chile. Quaternary Research 65, 450-466.

Le Roux, J.P., 2012. A review of Tertiary climate changes in southern South America and the Antarctic Peninsula. Part 2: continental conditions. Sedimentary Geology 247-248, 21-38. Revista Geológica de Chile 32, 33-58.

Naish, T., Carter, L. , Wolff, E., Pollard, D., Powell, R., 2008. Late Pliocene-Pleistocene Antarctic Climate 342 Variability at Orbital and Suborbital Scale. Ice Sheet, Ocean and Atmospheric Interactions. Developments in 343 Earth \& Environmental Sciences 8, 465-529.

Naranjo, J.A., Paskoff, R.P., 1982. Estratigrafía de las unidades sedimentarias cenozoicas de la Cuenca del

Río Loa en la Pampa del Tamarugal, Región de Antofagasta, Chile. Revista Geológica de Chile 15, 49-57. hyperarid Atacama Desert of northern Chile during the latest Pleistocene. Proceedings of the National Academy of Sciences 104, 19724-19729. 
Pisera, A., Sáez, A., 2003.Paleoenvironmental significance of a new species of freshwater sponge from the

Placzek, C., Quade, J., Patchett, P.J., 2006. Geochronology and stratigraphy of the late Pleistocene lake cycles on the southern Bolivian Altiplano. Implications for causes of tropical climate Change. GSA Bulletin $118,515-532$.

Pueyo, J.J., Chong, G., Jensen, A., 2001. Neogene evaporites in desert volcanic environments. Atacama

Desert, northern Chile. Sedimentology 48, 1411-1431.

Rabassa, J., Coronato, A.M., Salemme, M., 2005. Chronology of the Late Cenozoic Patagonian glaciations and their correlation with biostratigraphic units of the Pampean region (Argentina). Journal of South American Earth Science 20, 81-103.

Rech, J.A., Currie, B., Michaslski, G., Cowan, A.M., 2006. Neogene climate change and uplift in the Atacama

Rech, J.A., Currie, B., Shullenberger, E.D., Dunagan, S.P., Jordan, T.E., Blanco, N., Tomlinson, A.J., Rowe.

H.D., Houston, J., 2010. Evidence for the development of the Andean rain shadow from a Neogene isotopic record in the Atacama Desert, Chile. Earth and Planetary Science Letters 292, 371-382.

Sáez, A., Cabrera, L., Jensen, A., Chong, G., 1999. Late Neogene lacustrine record and paleogeography in the Quillagua-Llamara basin, Central Andean fore-arc (northern Chile). Palaeogeography,

Tiedemann, R., Mix, A.C., 2007. 1. Leg 202 Synthesis: Southeast Pacific Paleoceanography. In Tiedemann,

378 R., Mix, A.C., Blum, P. and Ruddiman, W.F. (Eds.). Proceedings of the Ocean Drilling Program, Scientific 
381 Tomlinson, A.J., Blanco, N., Maksaev, V., Dilles, J.H., Grunder, A.L., Ladino, M., 2001. Geología de la

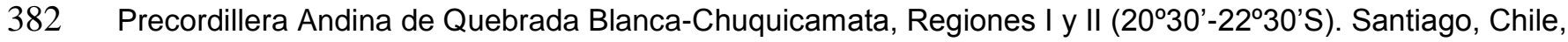
383 Servicio Nacional de Geología y Minería, Informe Registrado IR-01-20, 2 volumes, 444 p.

384

385 Wara, M., Ravelo, A.C., Delaney, M.L., 2005. Permanent El Niño conditions during the Pliocene warm 386 period. Science 309, 758-761.

387

388 Zachos, J., Pagani, M., Sloan, L., Thomas, E., Billups, K., 2001. Trends, rhythms and aberrations in global 389 climate 65 Ma to present. Science 292, 686-693. 
$391 \quad$ Figure and table captions

392 Figure 1. A. Location map showing present-day climatic zones of western South America; box shows area of

393 map B. B. Geological sketch of the Quillagua and Calama basins. Red circles named (MAN, TAM, MO, TA,

394 TE, ARC, CON, EN, ESQ, PUP) correspond to 10 sections in the central and the eastern margin of the

395 Quillagua Basin where 14 tephra layers have been dated by ${ }^{40} \mathrm{Ar} /{ }^{39} \mathrm{Ar}$ (Table 1). Numbers in bold indicate

396 sections in panel of Fig. 2. 1. Cerro Mogote section (MO), 2. Quebrada Tambillo section (TA), 3. Quebrada

397 Temblor-Río Loa composite section (TE-FTE), 4. Puente Posada section (PUP). The main lacustrine units in

398 Quillagua and the alluvial successions outcropping in both basins are mapped.

400 Figure 2. N-S stratigraphic cross section showing lithologic and paleomagnetic units of central areas of the

401 Quillagua Basin and the diverse bounding unconformities and hiatuses. Blue line depicts changes in the

402 lacustrine facies (Sáez et al., 1999) and represents higher order transgressive-regressive lacustrine

403 sequences recording $\sim 20 \mathrm{kyr}$ precession cycles. Red line depicts lower order sequences recording $\sim 400$-kyr

404 eccentricity cycles.

405

406 Figure 3. Correlation of sedimentation and non-sedimentation stages in the central part of the Quillagua 407 Basin and the meridional-distal margin of Calama Basin. Antarctic climate events affecting South America, 408 Patagonian glaciations and changes of upwelling water temperatures during last $10 \mathrm{Ma}$ are included 409 (Rabassa et al., 2005; Haywood et al., 2008: Naish et al, 2008; Abe et al., 2006; Tiedemann and Mix, 2007).

410 The colors in the bar that represents upwelling water temperature are a qualitative indication of the overall 411 trends of temperature change while the superimposed curve of temperature corresponding to the last 6 412 million years has been adapted from Abe et al., 2006. Eccentricity (E) and precession (P) cycles recorded 413 during the late Miocene-early Pliocene depositional stage are shown. The short term episodes of water 414 contribution from the higher altitude zones to the East of Atacama Desert and likely linked to the 415 reinforcement of the South American Summer Monsoon during La Niña-like situation are also shown. 1. 416 Artola ignimbrite at the top of Jalquinche Fm (10.3/9.4 Ma; Blanco, 2008), 2. Sifón ignimbrite interbedding 417 Chiquinaputo Fm (7.82 Ma, Rech et al., 2010), 3. Near bottom of Opache Fm (5.76 Ma; May 2005), 4. Top 418 Opache Fm (3.37 Ma; May et al., 2005), 5. Chiu-Chiu Fm (between 3.37 and 0.45 Ma; Blanco, 2005). 6. 419 Lower outcropping Hilaricos Unit (paleomagnetic data, this study), 7. Near top Hilaricos Unit, $8.75 \mathrm{Ma}$ (this 420 study), 8. Top Hilaricos Unit (paleomagnetic data, this study), 9. Top of red distal Arcas deposits 421 (paleomagnetic data, this study), 10. Bottom of Quillagua Fm (5.54/5.36 Ma, this study), 11. Eroded top of 422 Quillagua Fm (paleomagnetic data, this study). 12. Near bottom of Soledad Fm (0.2-0.1 Ma, this study). 
423

424 Table $1 .{ }^{40} \mathrm{Ar} /{ }^{39} \mathrm{Ar}$ date of sampled tephra layers from Quillagua Basin. Location, unit and tephra layer 425 characteristics are also included. See map of figure 1 for section samples location. 


\section{Highlights}

- Stratigraphic record in Atacama over the last $10 \mathrm{Ma}$ includes two hiatuses

- The two hiatuses lasted 2 and 4 million years

- The hiatuses represent periods of hyperaridity in the region

- Gaps are synchronic with Antarctic glaciations and Humboldt C. enhancement

- South American Summer Monsoon modulated the hyperaridity trends. 


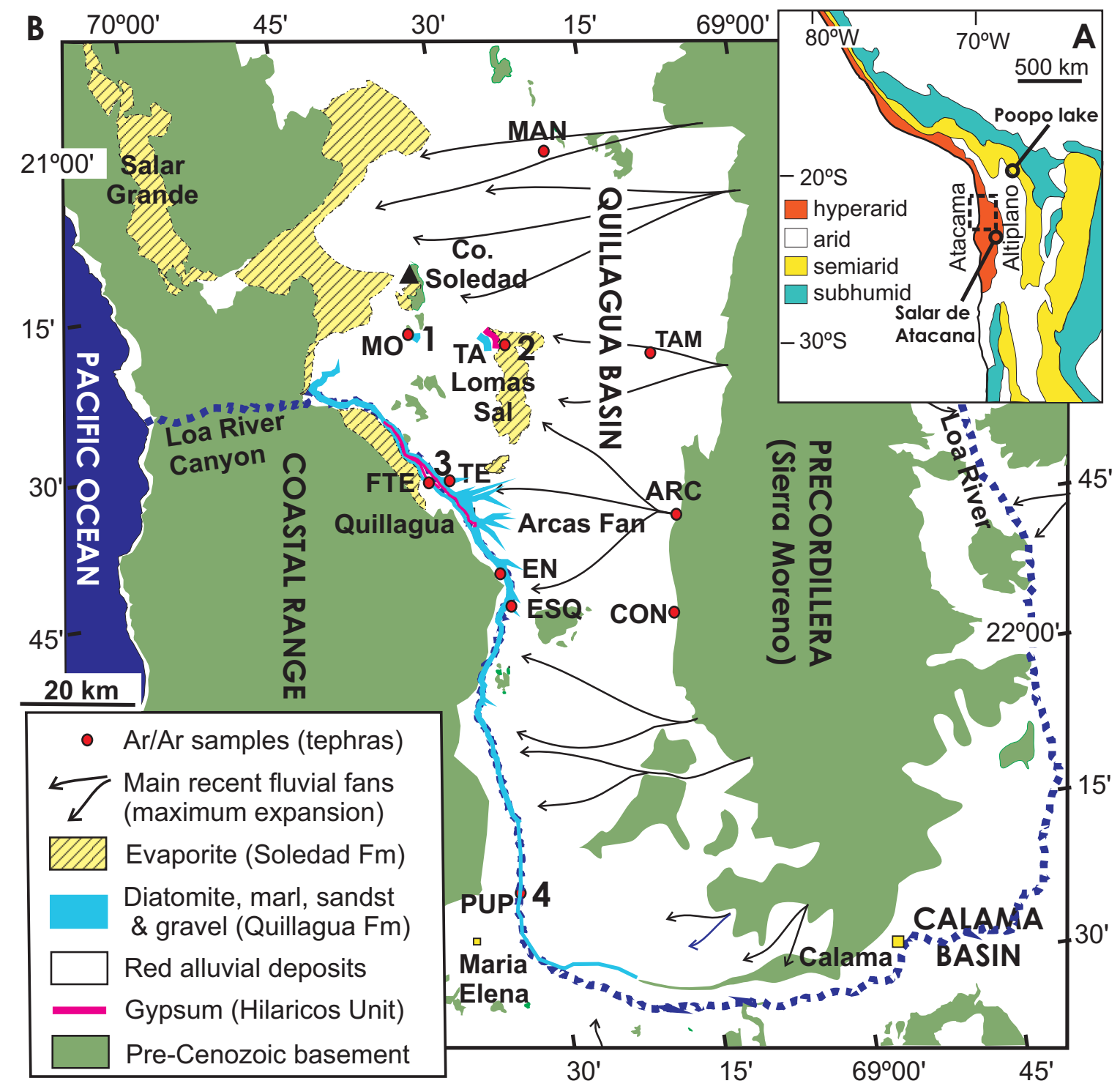




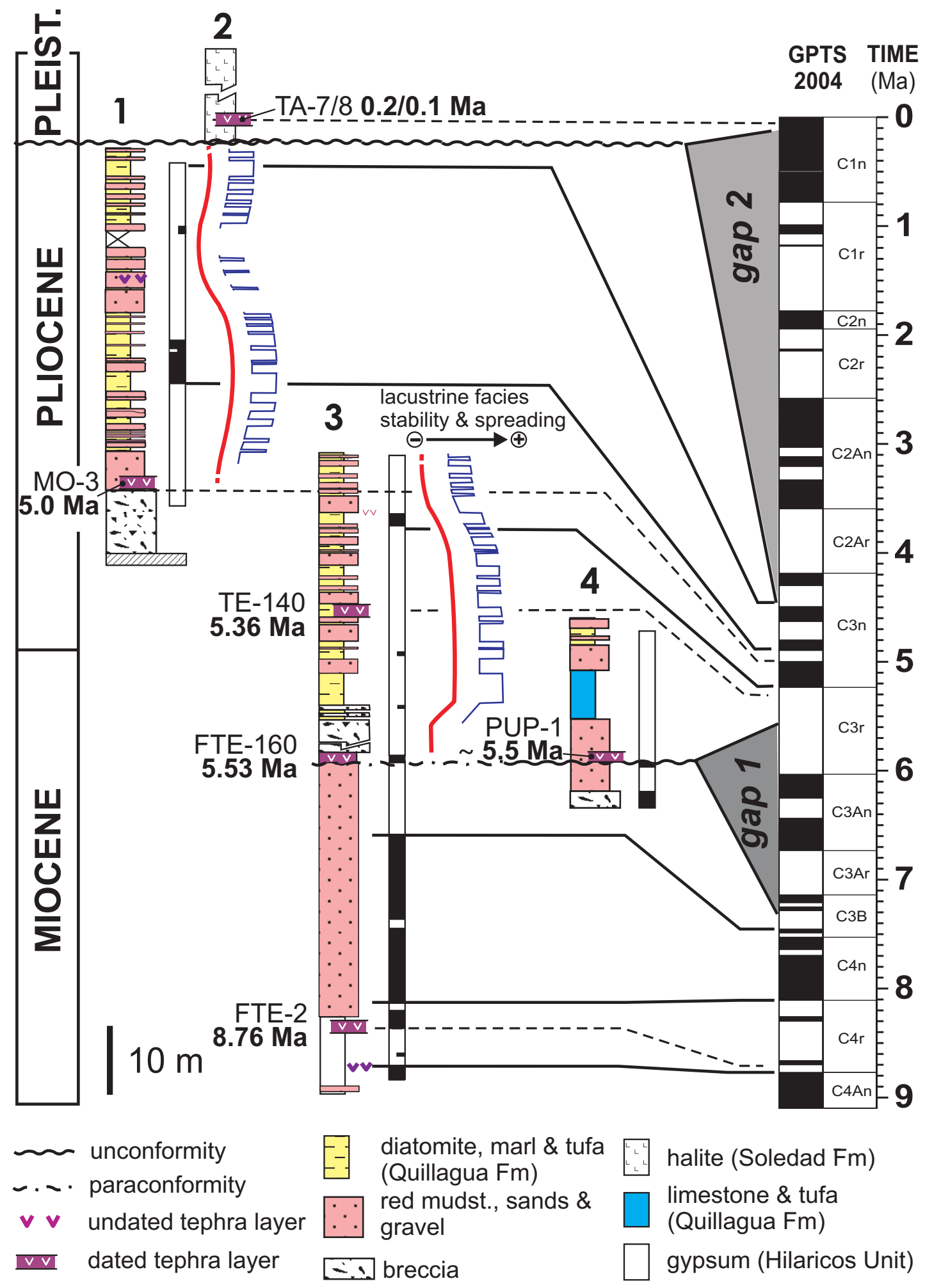




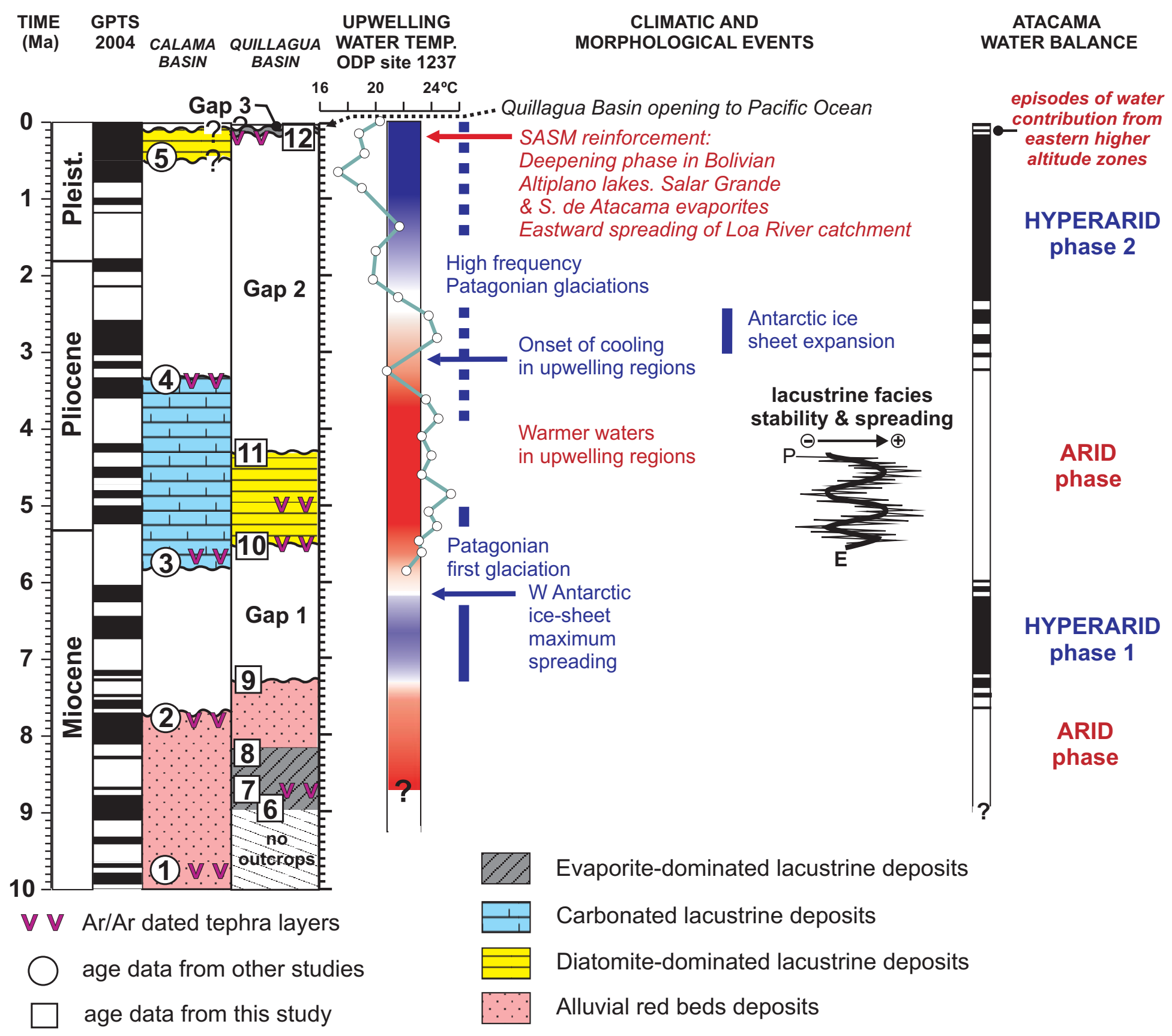




\begin{tabular}{|c|c|c|c|c|c|c|c|c|c|c|c|c|c|}
\hline \multirow[t]{2}{*}{ Sample } & \multirow[t]{2}{*}{ Lab No. } & \multicolumn{2}{|c|}{ Coordinates } & \multirow[t]{2}{*}{ Location, unit and tephra layer characteristics } & \multirow[t]{2}{*}{ Material } & \multirow{2}{*}{$\begin{array}{l}\text { Type of } \\
\text { data }\end{array}$} & \multirow{2}{*}{$\begin{aligned} \text { Age } \\
(\mathbf{M a})\end{aligned}$} & \multirow{2}{*}{ $\pm 2 \sigma$} & \multirow[t]{2}{*}{ MSWD } & \multirow[t]{2}{*}{ Probability } & \multirow[t]{2}{*}{$\%^{39} \mathrm{Ar}$} & \multirow{2}{*}{$\begin{array}{l}\text { Number of } \\
\text { steps }\end{array}$} & \multirow{2}{*}{$\begin{array}{l}\text { Plateau steps } \\
\text { alteration } \\
\text { index }\end{array}$} \\
\hline & & Latit. S & Long. W & & & & & & & & & & \\
\hline TA8 & TA8btsi & $21^{\circ} 23^{\prime} 51^{\prime \prime}$ & $69^{\circ} 25^{\prime} 10^{\prime \prime}$ & $\begin{array}{l}\text { Co. Tambillo Alto in Lomas de la Sal. Lower Soledad Fm. } \\
\text { Crusted layer between halite layers }\end{array}$ & Biotite & Plateau & 0.21 & \pm 0.066 & 0,44 & 0.85 & 65.5 & 10 to 16 of 18 & $<0.001$ \\
\hline TA7 & TA7btsi & $21^{\circ} 23^{\prime} 51^{\prime \prime}$ & $69^{\circ} 25^{\prime} 10^{\prime \prime}$ & $\begin{array}{l}\text { Co. Tambillo Alto in Lomas de la Sal. Lower Soledad Fm. } \\
35 \mathrm{~cm} \text {-thick layer between halite layers }\end{array}$ & Biotite & $\begin{array}{l}\text { Plateau } \\
\text { (low-prob.) }\end{array}$ & 0.098 & \pm 0.042 & 3.0 & 0,02 & 52.1 & 9 to 13 of 14 & $<0.0005$ \\
\hline ESQ1 & ESQ1bts & $21^{\circ} 49^{\prime} 01^{\prime \prime}$ & $69^{\circ} 29^{\prime} 28^{\prime \prime}$ & $\begin{array}{l}\text { Paso Borax of Loa river. Distal alluvial E } \\
\text { Margin.Lenticular layer in channel } 2.30 \text { m-thick }\end{array}$ & Biotite & Plateau & 0.151 & \pm 0.033 & 0.98 & 0.46 & 93 & 7 to 17 of 18 & $<0.0005$ \\
\hline CON1 & CON1bt2 & $21^{\circ} 51^{\prime} 16^{\prime \prime}$ & $69^{\circ} 14^{\prime 2} 27^{\prime \prime}$ & $\begin{array}{l}\text { Los Condores sector, E alluvial margin. Layer } 50 \mathrm{~cm} \text {-thick } \\
\text { above a breccia }\end{array}$ & Biotite & $\begin{array}{l}\text { Plateau } \\
\text { (low-prob.) }\end{array}$ & 0.181 & \pm 0.056 & 2.9 & 0.003 & 88.5 & 9 to 17 of 19 & $<0.0005$ \\
\hline TE140 & TE140fss & $21^{\circ} 36^{\prime} 00^{\prime \prime}$ & $69^{\circ} 33^{\prime} 07^{\prime \prime}$ & $\begin{array}{l}\text { Qda. Temblor. Mid Quillagua Fm, } 10 \text { cm-thick between } \\
\text { diatomites }\end{array}$ & Feldspar & $\begin{array}{l}\text { Single step } \\
\text { age }\end{array}$ & 5.36 & \pm 0.05 & - & - & 60.4 & step 19 of 19 & 0.00004 \\
\hline FTE160 & FTE160bts & $21^{\circ} 35^{\prime} 47^{\prime \prime}$ & $69^{\circ} 35^{\prime} 01^{\prime \prime}$ & $\begin{array}{l}\text { Western side Rio Loa, in front of Qda. Temblor. At the } \\
\text { base of Quillagua Fm. Several layers, } 5 \text { to 7-m thick }\end{array}$ & Biotite & Plateau & 5.535 & \pm 0.036 & 1.08 & 0.37 & 94.5 & 7 to 17 of 19 & $<0.001$ \\
\hline MO29 & MO29bts & $21^{\circ} 21^{\prime} 08^{\prime \prime}$ & $69^{\circ} 34^{\prime} 42^{\prime \prime}$ & $\begin{array}{l}\text { Cerro Mogote. Mid Quillagua Fm, tabular layer } 30 \mathrm{~cm} \\
\text { thick }\end{array}$ & Biotite & $\begin{array}{l}\text { All steps } \\
\text { weighted } \\
\text { mean }\end{array}$ & 5.55 & \pm 0.2 & 6.6 & 0,000 & 100 & 1 to 20 of 20 & $\begin{array}{c}0.002-0.4 \\
\text { (strongly } \\
\text { altered) }\end{array}$ \\
\hline MO3 & MO3bts & $21^{\circ} 21^{\prime} 5.81$ & 69³4'39" & $\begin{array}{l}\text { Cerro Mogote. Lower Quillagua Fm., tabuler layer } 20 \mathrm{~cm} \\
\text { thick. }\end{array}$ & Biotite & Plateau & 5.046 & \pm 0.034 & 2.2 & 0.063 & 55.9 & 12 to 16 of 20 & $<0.0005$ \\
\hline PUP1 & PUP1bts & $22^{\circ} 16^{\prime} 39^{\prime \prime}$ & 69³3'37" & $\begin{array}{l}\text { Puente Posada. Quillagua Fm base. Lenticular layer } 1 \mathrm{~m} \text { - } \\
\text { thick in a chanel between red mudstones }\end{array}$ & Biotite & $\begin{array}{l}\text { Plateau } \\
\text { (low-prob.) }\end{array}$ & 5.66 & \pm 0.12 & 3.4 & 0.009 & 58.3 & 13 to 17 of 20 & $<0.0005$ \\
\hline TAM2 & TAM2bts & $21^{\circ} 26^{\prime} 41^{\prime \prime}$ & $69^{\circ} 10^{\prime} 59^{\prime \prime}$ & Qda. Tambillo. E Alluvial margin. & Biotite & Plateau & 5.303 & \pm 0.043 & 0.81 & 0.58 & 89.1 & 10 to 17 of 20 & $<0.001$ \\
\hline ARC2 & ARC2bt2 & $21^{\circ} 42^{\prime} 59^{\prime \prime}$ & $69^{\circ} 10^{\prime} 59^{\prime \prime}$ & $\begin{array}{l}\text { Qda. Arcas, E Alluvial margin. Layer, } 3 \mathrm{~m} \text { thick, between } \\
\text { conglomerates. } 5 \mathrm{~m} \text { below ARC3 }\end{array}$ & Biotite & Plateau & 5.509 & \pm 0.032 & 1.9 & 0.088 & 65 & 11 to 16 of 18 & $<0.001$ \\
\hline ARC3 & ARC3bts & $21^{\circ} 42^{\prime} 59^{\prime \prime}$ & $69^{\circ} 10^{\prime} 59^{\prime \prime}$ & $\begin{array}{l}\text { Qda. Arcas, E Alluvial margin. Lenticular layer, } 5.5 \text { m } \\
\text { max. thick between conglomerates }\end{array}$ & Biotite & Plateau & 5.369 & \pm 0.031 & 1.8 & 0.095 & 74.1 & 11 to 17 of 20 & $<0.001$ \\
\hline MAN4 & MAN4bts & $21^{\circ} 05^{\prime} 47^{\prime \prime}$ & $69^{\circ} 16^{\prime} 03^{\prime \prime}$ & $\begin{array}{l}\text { Qda. Mani. E alluvial margin. Layer } 20 \mathrm{~cm} \text {-thick between } \\
\text { conglomerates, near top of the sequence }\end{array}$ & Biotite & Plateau & 8.76 & \pm 0.05 & 1.4 & 0.18 & 77.2 & 7 to 18 of 18 & $<0.001$ \\
\hline FTE2 & FTE2bts & $21^{\circ} 35^{\prime} 47^{\prime \prime}$ & $69^{\circ} 35^{\prime} 01^{\prime \prime}$ & $\begin{array}{l}\text { Western side Rio Loa, in front of Qda. Temblor. Hilaricos } \\
\text { Unit, top }\end{array}$ & Biotite & Plateau & 8.756 & \pm 0.046 & 1.8 & 0.09 & 71.1 & 11 to 17 of 20 & $<0.001$ \\
\hline
\end{tabular}

Plateau criteria: at ${ }^{40} \mathrm{Ar}^{36} \mathrm{Ar}_{\mathrm{i}}=295.5 ;>3$ consecutive steps identical within 2Sigma, $95 \%$ confidence level, probablity $>5 \% ;{ }^{39} \mathrm{Ar}$ fraction $>50 \%$. Biotite alteration index $={ }^{36} \mathrm{Ar} /{ }^{39} \mathrm{Ar}$ corrected for ${ }^{36} \mathrm{Ar}$ Ca and normalized to $\mathrm{J}=0.01$ and $\mathrm{K}=8 \%$ ( $<0.0005$ for fresh biotite step-heating plateau steps). Feldspar (plagioclase) alteration index $={ }^{36} \mathrm{Ar}{ }^{37} \mathrm{Ar}$ corrected for ${ }^{36} \mathrm{Ar}_{\mathrm{Ca}}$ and normalized to $\mathrm{J}=0.01$ ( $<0.00006$ for fresh plagioclase stepheating plateau steps) (Baksi, 2007). 
Supplementary mat Fig. 1

Click here to download Supplementary material for on-line publication only: Suppl Figure 1 Zijd-plots EPSL_LR.pdf

(

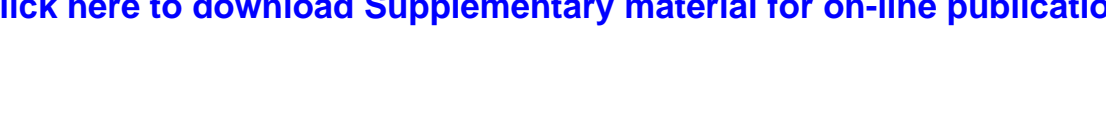

(n)

西 (1) 西 (1) . . . . . . . . . . . . . . . . . 

Supplementary mat. Fig. 2
Click here to download Sup

Click here to download Supplementary material for on-line publication only: Suppl Figure 2 logs_EPSL.pdf 